\title{
Children's Digital Practices: Case Studies Of Children Viewing And Representing With Digital Text
}

Daniel Churchill, University of Hong Kong, Republic of China

Kay Yong Khoo, University of Hong Kong, Republic of China

\begin{abstract}
This paper reports on case studies of four primary school children and their digital practices in Hong Kong. The study explored how the participating children view and represent through digital text in the context of their out-of-school technology use. Understanding how these practices extended into their English language classrooms was explicated based on emerging data. The study results identify six aspects of emerging skills acquired by the children. These skills were not extended into the children's schoolwork - a reflection on the emphasis on uni-modal language learning in the class setting. A detailed examination of the individual skills led to a set of recommendations for curriculum review, suitable pedagogical strategies and classroom learning resources that English Language Educators may utilize to facilitate development of viewing and representing skills through digital text.
\end{abstract}

Keywords: Digital Practices; Primary School Children

\section{INTRODUCTION}

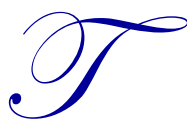

he meaning of literacy in the $21^{\text {st }}$ century has changed markedly with emerging and now dominant technologies: that is, the move away from writing to the new digital text mode, and from the medium of the book to that of the monitor screen(Kress, 2010). It is therefore important to extend the notion of literacy beyond the traditional modes of speaking, listening, writing and reading to include digital text and communication.

Language curricula in primary schools around the world are being revised in countries such as the United Kingdom, Canada, Singapore and Australia to incorporate new forms of literacies(Department for Children schools and families UK, 2009; Ministry of Education Ontario, 2006; MOE Singapore, 2010; National Curriculum Board Australia, 2008). These literacies are then proposed as the prerequisite in the effective consumption of digital texts and communication through contemporary technologies(Kress \& Jewitt, 2003; Len Unsworth, 2008).

Today's technologies allow children to engage with digital text on a regular basis outside school (Buckingham \& Willett, 2006; Kimber \& Claire, 2008; Prensky, 2001a). However, the emerging extra-school skills that are acquired from interacting and communicating with digital text remain unexplored. Digital text incorporates all four macro-skills of listening, speaking, reading and writing, but requires additional skills including frequent use of visuals, dynamic information, and interaction.

Contemporary language curricula in schools need to incorporate emerging literacies (Jewitt, 2006; Kress, 2003; Martinec \& Leeuwen, 2009). Language is broadly understood as the main meaning-making resource for constructing and consuming information (Len Unsworth, 2008). However, in Hong Kong, the government-mandated primary school's curriculum of English Language has not incorporated digital text as an integral aspect of Language learning (Education and Manpower Bureau HK, July 2004). To incorporate digital text into the language curriculum, a viable set of recommendations is needed to address the skills required to engage with the emerging literacies. 
There is an emerging gap between children's out-of-school digital practices and practices in the primary school English Language classroom in Hong Kong (which remain focused on linguistic learning). The literature suggests four areas of digital practices that impact the engagement on monitor screens:

1. The ability to recognize and create elements in different modes (Jewitt, 2006; Len Unsworth, 2008);

2. The ability to apply the affordances of modes in meaning making (Jewitt, 2006; Kress, 2003; Martinec \& Leeuwen, 2009);

3. The ability to link elements of information in different modes contextually in spatial or temporal layouts (Kress, 2010; Leeuwen, 2005); and

4. The ability to navigate on screens (Leeuwen, 2005; Martinec \& Leeuwen, 2009).

These four areas of digital practices are also evidenced among the children, who participate in various social networking sites regularly. Their semantic practices involve not just engagement with written text, but also elements of other modes (Connelly, 2008; Cope \& Kalantzis, 2000; Len Unsworth, 2008). The escalation of their engagement on different sites has resulted in children of today quickly adapting to the different navigation potential on screens (Gee, 2003; Prensky, 2001b). They are also obtaining screen-based information with different layouts of different mode composition (Walsh, Asha, \& Sprainger, 2007). Based on this concise review, we may conclude that there are skills to be derived from children's intuitive understandings arising from their natural interactions with digital text. The skills utilize but are additional to listening, speaking, reading and writing, and involve frequent use of visuals, dynamic information, and interaction through digital text. Such skills are categorized in the literature as viewing and representing (Kress, 2010; MOE Singapore, 2010).

Hong Kong is currently in a transition where the primary school English Language curriculum has not yet incorporated changes in the new literacies. The purpose of this study was to investigate in detail aspects of participating children's viewing and representing skills and how they extended their viewing and representing skills into their formal schoolwork and independent school projects.

\section{METHODOLOGY}

The study explored four cases of primary school-aged children. The methodology of the study was qualitative (Gay, Mills, \& Airasian, 2006; Merriam, 1988, 2009; Yin, 1994). The study explored digital practices that emerged from the children's out-of-school uses of technology and how these extended to formal school activities, whether initiated by teachers in formal learning, or applied independently by the children in their independent schoolwork. Two research questions guided the data collection and analysis of this study:

1 What digital literacy practices emerge from the participating children's out-of-school technology use?

$2 \quad$ How have these practices been extended to school activities?

Students were recruited using a purposeful sampling strategy at a tuition centre in Hong Kong. The centre operates primary school English Language tuition classes supplementary to the Hong Kong government school syllabus. It has implemented an e-learning system to support delivery of its program. Four children were selected according to the three selection criteria determined by the researcher in order to obtain rich qualitative data. These criteria were: (i) participants regularly viewed or represented messages in blogs or social media tools like Facebook; (ii) they used the Internet at least weekly and (iii) they were students from primary-six level, the highest level of primary school. The research also investigated the children's digital-related schoolwork in their school.

The collection of data occurred over a period of eight months. The study included observations, video recordings, interviews and personal documents (digital artifacts) study and was structured into two stages (see Figure 1). The study was explorative. It involved collection of visual and narrative data and digital artifacts during the two stages. Stage One focused on exploring the viewing and representing skills of the participating children. Stage Two focused on how the children extend the skills into their school activities. Understandings emerging from the first stage of the study facilitated data collection in the second stage. 


\section{PARTICIPANTS}

Four cases were identified after discussing the selection criteria with the teachers. The participating children were from different schools and had enrolled themselves in the same tuition centre.

The study participants' profiles are presented in Table 1. Pseudonyms are used to safeguard their anonymity. The study was conducted after relevant ethical clearance was secured. Initially, a group of children were briefed about the study and roles of participants before being asked to consider participating. Those who agreed to participate were given a consent form to take home to their parents. Signed parental consent was required.

Table 1.The details derived from the selection criteria for the four cases

\begin{tabular}{cccc}
\hline Participant * & $\begin{array}{c}\text { Hours/Week spent } \\
\text { with Computers }\end{array}$ & $\begin{array}{c}\text { Regular Viewing } \\
\text { and Representing Activities }\end{array}$ & Gender/Level \\
\hline Angel & 16 & Facebook.com & Female/ Primary 6 \\
\hline Winnie & 4 & myblog.yahoo.com & Female/Primary 6 \\
\hline Nicole & 3 & Qooza.hk & Female/ Primary 6 \\
\hline Wong & 4.5 & Facebook.com & Female/Primary 6 \\
\hline * Pseudonyms are used to protect the participants' identities. & &
\end{tabular}

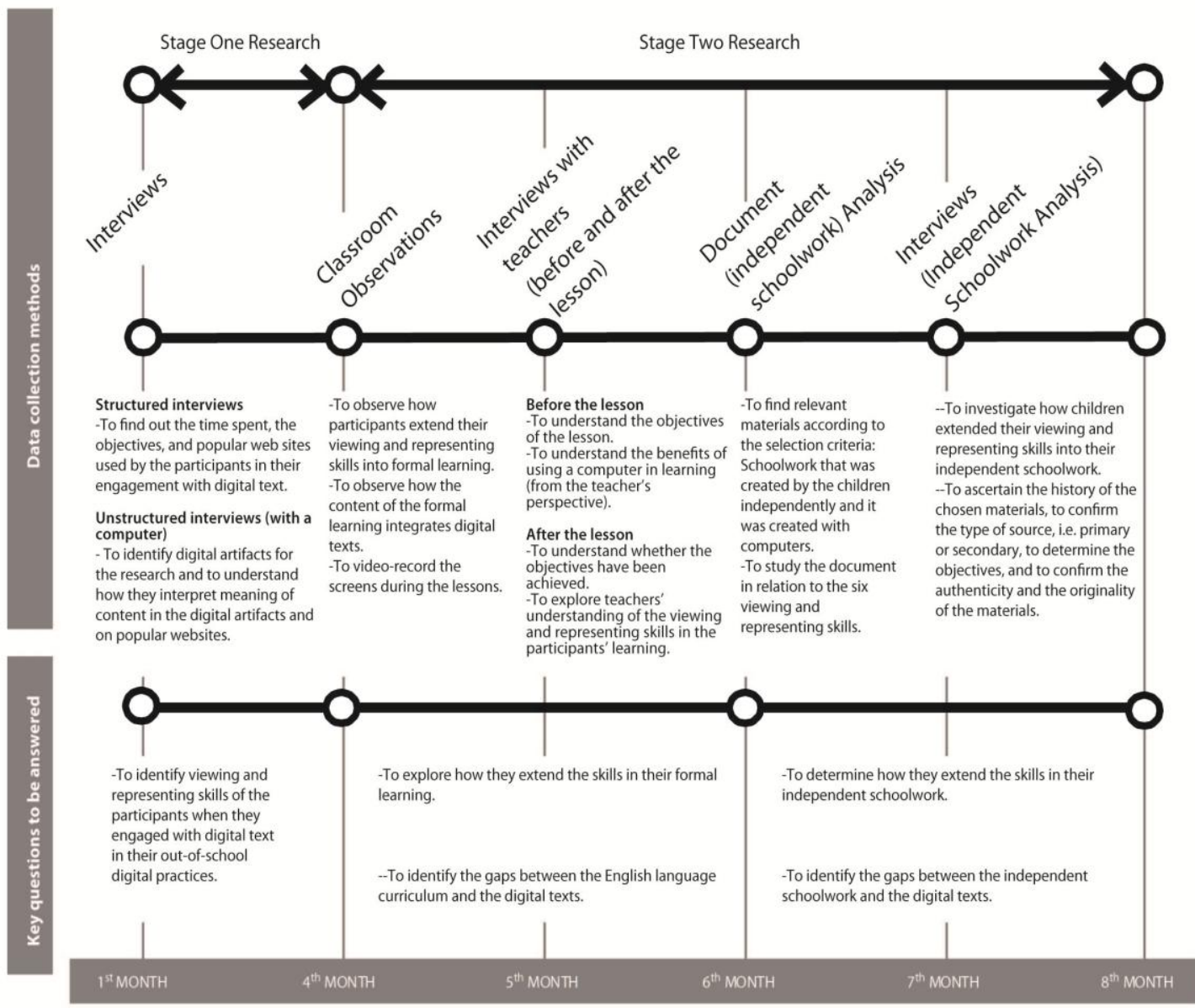

Figure 1. The Procedure of The Research Methodology 


\section{RESULTS: THE DIGITAL SKILLS DEVELOPED BY THE PARTICIPANTS}

\section{Participant One: Angel, a multi-mode representing practitioner}

Angel is an eleven-year-old girl from a middle-class Hong Kong Chinese family. For her, technology was an important part of her life. She claimed that her hobby was to design with graphic design software, such as Windows Paints and Photoshop. She also stated that she communicated regularly with her friends in Facebook; she read and replied to messages from her friends and created new messages in her social networking account. The researcher found that in her Facebook messages, the information was in multi-modes - i.e. videos, images, verbal narrations and writing. From day one of the study, Angel demonstrated a strong tendency to seek out information on the Internet, including looking up the meaning of words with online dictionaries. The researcher requested Angel to suggest interesting messages in her Facebook account using images, video clips or songs (i.e., semantic digital artifacts demonstrating diversity in the modes used). Three digital artifacts were selected from Angel's messages listed in her Facebook.

From the study at Stage One (as in Figure 1) of the three digital artifacts and Angel's engagement on different web sites, the researcher found that she had acquired the following abilities:

i. To engage with multi-mode elements. The new literacies require users to engage with elements in different modes (Jewitt, 2006; Len Unsworth, 2008). She was competent in both recognizing and creating messages with elements of different modes -, i.e. video, verbal narrations, images and printed texts.

ii. To apply affordances of modes in meaning making. Different modes offer different potentials of meaning making, i.e. the affordances of modes (Kress, 2010).

Images

According to Kress, one of the affordances of images is to provide depictive information. Angel applied a newspaper cutting to show the authentic aspect of the message as in Figure 2. In Figure 3, she used her serious look photo to reflect her friends' perception of her.

Writing

Kress claims that writing affords the description of ideas. Angel urged readers of her message to tell more people (as in Figure 2) about the news she had read that live puppies were used as shark bait; and she determined to change the image she was projecting of herself by using smiley faces to get to know more friends (as in Figure 3).

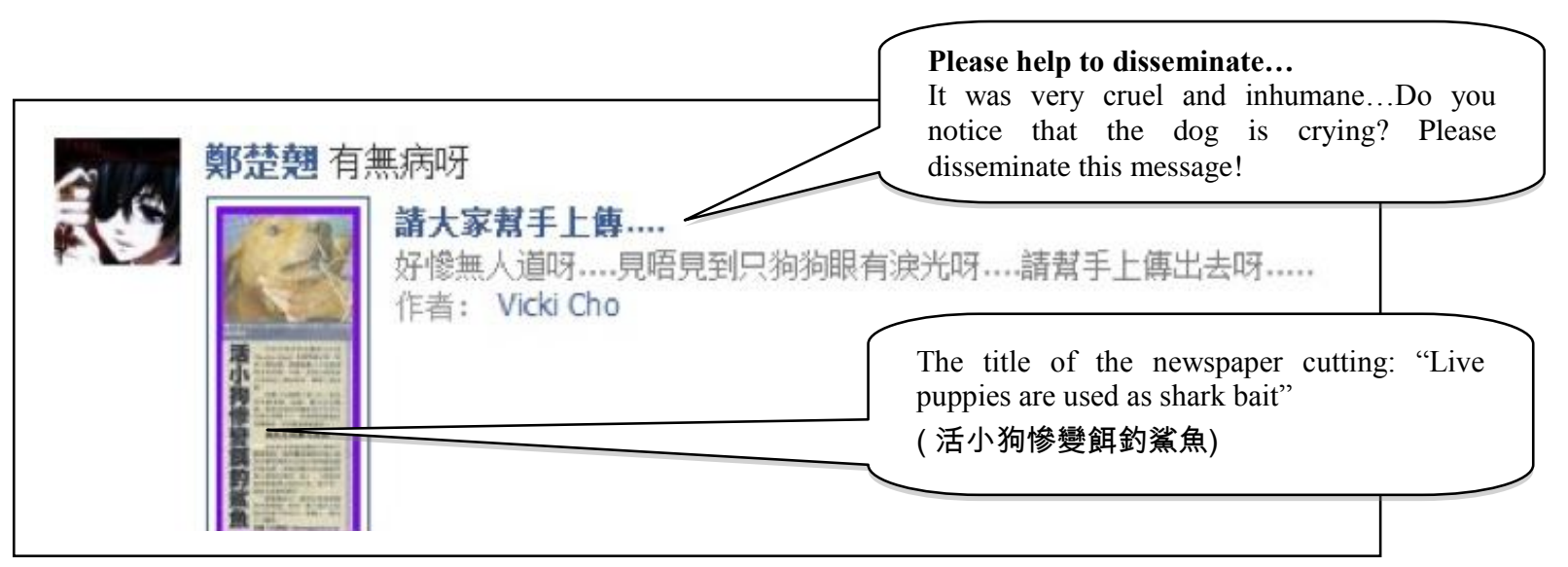

Figure 2. Angel's digital artifact with the title "Puppies As Fishing Bait." 


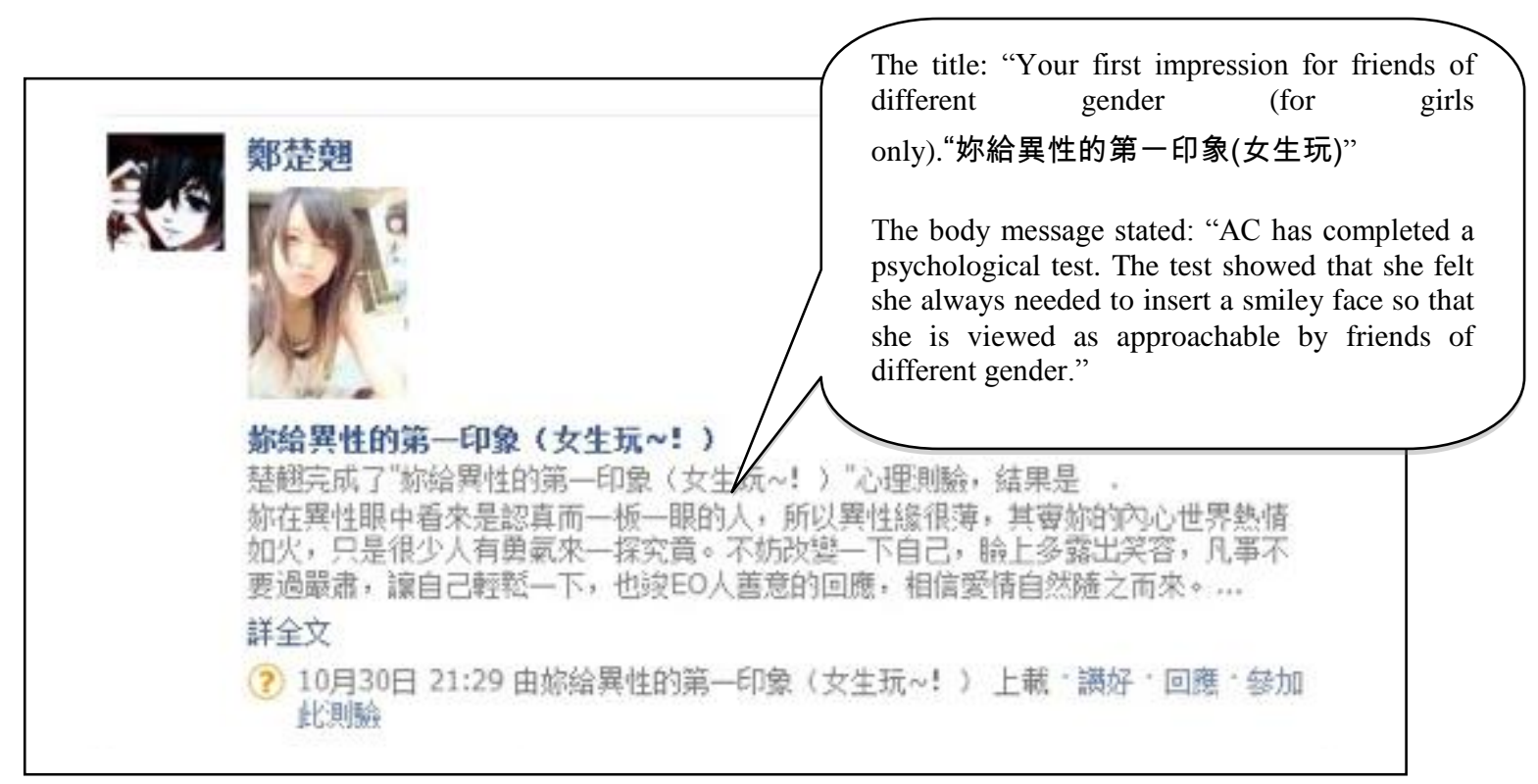

Figure 3. The digital artifact by Angel with the title: A Psychological Test

Videos

Also, according to Kress, videos provide information that demand changes of time or space, or information that is perceived through sight and hearing (emotion, attitudes, and etc.). Angel applied a video clip that showed a series of images with different narration for each, "The Handsome Guys and The Ugly Guys (http://www.youtube.com/watch?v=vZhSvMRiXtE)". The narrations with illustrations compared how people perceived handsome and ugly boys performing a series of heterogeneous actions. For example: when a handsome boy reads a book, people would praise him as "a decent boy", but an ugly boy reading a book would be termed a "bookworm".

iii. To link elements of different modes meaningfully in layouts. One of the values of information on screens lies in its contextual links. The links integrate elements of information in different modes contextually in spatial or temporal layouts (Kress, 2010; Leeuwen, 2005); Angel demonstrated her understanding to elaborate on the title (writing) with the newspaper cutting (an image) as in Figure 2, and to complement the body message (writing) with a photo (an image) as in Figure 3.

iv. To navigate information on screens with hypertexts. Hypertexts differ from traditional texts. They afford readers interaction with text in a manner that is meaningful to them (Jonassen, 1986; Leeuwen, 2005; Martinec \& Leeuwen, 2009). The researcher found that Angel could quickly adapt to the navigation potential and the processing of digital texts of different modes.

On top of the four digital practices that have been noted from the literature, two additional skills emerged specifically from the Stage One study. Angel had also acquired the following abilities:

v. To design the path of engagement on screens, in which she made her own inferences in the process of meaning making. This is obviously very different from reading written texts where the discourse and meaning are arranged by the author.

vi. To assimilate digital functionalities in learning. Angel demonstrated her competency in searching for information in Facebook and, as mentioned, in using an online dictionary during the interview.

Six mutually exclusive viewing and representing skills were identified. Furthermore, in Angel's three selected digital artifacts, the messages consisted of elements in different modes: i.e. images, sound, verbal narrations, video and writing. The researcher categorized her as a 'Multi-mode representing practitioner.' 
The second stage of the research was to find out how Angel extended her six viewing and representing skills into her English Language learning activities, which included her formal learning practices and her independent schoolwork. Four skills were found to have been extended from Stage One. Two were found in her formal learning:

1. Utilization of navigation skill (in her screen engagement she navigated with hyperlinks, multitasking and pop-up windows.).

2. Assimilating of digital functionality skill (she looked up words via Yahoo Dictionary, searched for information using Yahoo Search function and "copied and pasted" when editing her writing). Another two were found in her independent schoolwork.

3. Creating messages with elements of different modes skill (in PowerPoint, she created messages with images and writing).

4. Applying affordances of modes skill (She also applied the affordances of modes in the same writing and images). The school did not promote the use of monitor screens in assignments and independent schoolwork.

Interviewing of the teacher confirmed that the objectives of the lessons were to provide children with appropriate practices and knowledge as specified in the English Language curriculum. The teacher added that the lesson focused on tenses and comprehension practice. The focuses suggested that Angel's formal English Language learning with digital text focused on the writing mode (i.e. meaning is transpired through print) and the content appeared in linear forms (the continuous engagement of readers in a fixed sequence). The interview with Angel's teacher showed that she was aware of two viewing and representing skills:

1. "Assimilating digital functionalities" (as she commented: "Digital dictionaries can help children to learn independently"; "...it is easy to manage children's work in terms of submission and marking...") and

2. "Designing one's path of engagement" (the teacher stated, "Learning through computers can allow children to learn actively.")

\section{Participant Two: Winnie, a multimodal written text representing practitioner}

Winnie is an eleven-year-old girl. She engaged with the Internet for only two days per week, each session being of two hours duration. The engagement comprised listening to songs, playing games, and reading her blogs (she had a Yahoo blog account). She communicated with her friends through the blogs. Winnie preferred to use the writing mode in all her messages. She perceived that writing allowed her to express her feelings clearly to the reader.

In the first stage of research, four digital artifacts were selected from Winnie's out-of-school on-screen digital practices. From the data collection methods at Stage One as per Figure 1, the researcher observed that Winnie had acquired the same six viewing and representing skills. Although Winnie preferred to represent her messages in writing, the researcher noticed that she paid more explicit attention to the visual features of texts such as font size, formatting, paragraphing of main message and title. Winnie's written text provided meaning visually, more than linguistically. Messages in writing were treated as "resumes" (short statements). Winnie exhibited unique ways of presenting her messages in writing mode. The researcher classified her as a "multimodal written text representing practitioner".

In the second stage of the research, the researcher identified only 'screen navigation' and 'assimilating digital functionalities' - as having been extended into Winnie's formal learning. She could use hyperlinks, multitasking and pop-up windows in her navigation, and regularly searched online for information in her attempts to complete her formal learning practices on screen.

The interviews with the teacher confirmed that the objectives of the lesson focused on conjunctions in English grammar and comprehension. During the interviews, the teacher also acknowledged the presence of three viewing and representing skills: 
1. "Assimilating digital functionalities", as demonstrated when the teacher commented, "...the system can mark the children's schoolwork" and "...the online dictionary helps the child to look up the meaning of words."

2. The skill of "designing one's path of engagement", was acknowledged in the teacher's stating, “...the children are able to be more independent in learning.

3. The skill of "applying affordances of modes" was referred to when the teacher commented that "...the vocal reading can help children to understand the content better...."

\section{Participant Three: Nicole, a digital-savvy practitioner}

Nicole is a twelve-year-old girl. During the interview, the researcher observed her pulling out her smartphone to display her music and photos saved to the device. She gave the impression of routinely using her smartphone thus. At home, she accessed the computer twice per week. Each time she spent ninety minutes surfing the Internet. She used MS Office for some of her work, the school website to submit her schoolwork, MSN for communication and Yahoo to search for information related to her schoolwork. She also posted messages regularly on her blog at www.Qooza.hk and booked movie tickets online.

In the first stage of the research, five digital artifacts were selected from Nicole's out-of-school on-screen digital practices. The same six digital skills as observed in the previous cases were apparent in her engagement with Internet and from her digital artifacts. However, she demonstrated different uses and appreciation of digital functionalities. The researcher termed her a "digital savvy practitioner."

In Stage Two - formal learning research - four skills were extended from Stage One. 1. Nicole engaged with elements of multi-modes, namely images and writing. 2. She navigated on the screen with hyperlinks. 3. She was also found to have assimilated digital functions by editing her writing. 4. The last extended skill was apparent when Nicole designed her path of engagement to complete her schoolwork.

When interviewed, Nicole's teacher identified the titles of the lesson as English Grammar - i.e. verb agreement and comprehension practice. Both were in writing mode. In the same interview, the teacher demonstrated her awareness of three viewing and representing skills. That is, the skills of "designing one's path of engagement", "applying the affordances of modes", and "screen navigation".

\section{Participant Four: Wong, A Viewing Practitioner}

Wong is eleven years old. She was a quiet and shy girl. She averaged 3 days per week using computers, mostly for finishing school homework and leisure. She used MS Word for her schoolwork. Each computer session she spent 90 minutes surfing the Internet and communicating in Facebook. She looked up words and searched for information online.

In the first stage of the research, five digital artifacts were selected from Wong's out-of-school on-screen digital practices. Although her digital artifacts and engagement on-screens evidenced the same six viewing and representing skills as for previous cases, Wong was unique among the participants. She did not create much information on-screen, preferring to view and read instead. The researcher classified her as a "Viewing Practitioner."

The second stage of research indicated that she engaged with images and writing, navigated with hyperlinks and assimilated digital functionality by "copying and pasting" in her schoolwork.

The interview with her teacher before and after the lesson showed that the focuses of the lesson were on writing mode. However, the teacher was aware of three viewing and representing skills: "assimilating digital functionalities", "designing one's path of engagement" and "applying the affordances of modes". 


\section{DISCUSSION OF RESULTS AND RECOMMENDATIONS}

In this study, six viewing and representing skills are identified (as in Table 2) in response to the first research question. Four of these skills - skills 1,2,3 and 4 - were derived from practices identified in the literature review before the data collection (Jewitt, 2006; Kress, 2010; Kress \& Leeuwen, 2007; Leeuwen, 2005; Martinec \& Leeuwen, 2009). Two additional skills emerged from the study.

Table 2. Viewing and representing skills developed from children's out-of-school digital practices

\begin{tabular}{cl|l}
\hline Skill & \multicolumn{1}{c}{ Area } & \multicolumn{1}{c}{ Skill } \\
\hline One & Multi-mode & The skill to recognize and create elements of different modes on screen. \\
\hline Two Affordances of modes & $\begin{array}{l}\text { The skill to apply and engage with the affordances of different modes in digital practices on } \\
\text { screen. }\end{array}$ \\
\hline Three & Contextual Links & $\begin{array}{l}\text { The skill to interpret and create contextual links (in spatial/temporal layouts) with elements of } \\
\text { different modes. }\end{array}$ \\
\hline Four & Navigation & The skill to move around a screen to engage with information. \\
\hline Five & $\begin{array}{l}\text { Self-regulated path of } \\
\text { engagement }\end{array}$ & The skill to design one's own path of engagement with information on a screen. \\
\hline Six & Digital functionalities & The skill to assimilate digital functionalities in one's engagement on screen. \\
\hline
\end{tabular}

A summary of how these skills are extended into formal school learning and independent schoolwork is displayed in Table 3. The second research question will be answered based on these findings.

In investigating how children extended their viewing and representing skills into formal school learning, the researcher found that skills one, four, five and six were utilised, while skills two and three were not in evidence (as in Table 3).

The studies from the four cases show that English language learning at school focuses on linguistic development (such as grammar and reading comprehension) as observed in classroom observations and the interviews with the teachers. Although skill one (multi-mode) is extended as images in formal learning, the affordances of images (skill two) and the contextual links between images and writing mode (skill three) were not utilized. The result is consistent with the findings of other studies where images were found to be not utilized meaningfully in learning (Daly \& Unsworth, 2011; Len Unsworth, 2008).

Table 3. How primary school children extend viewing and representing skills learnt from their out-of-school digital practices into their formal and independent schoolwork

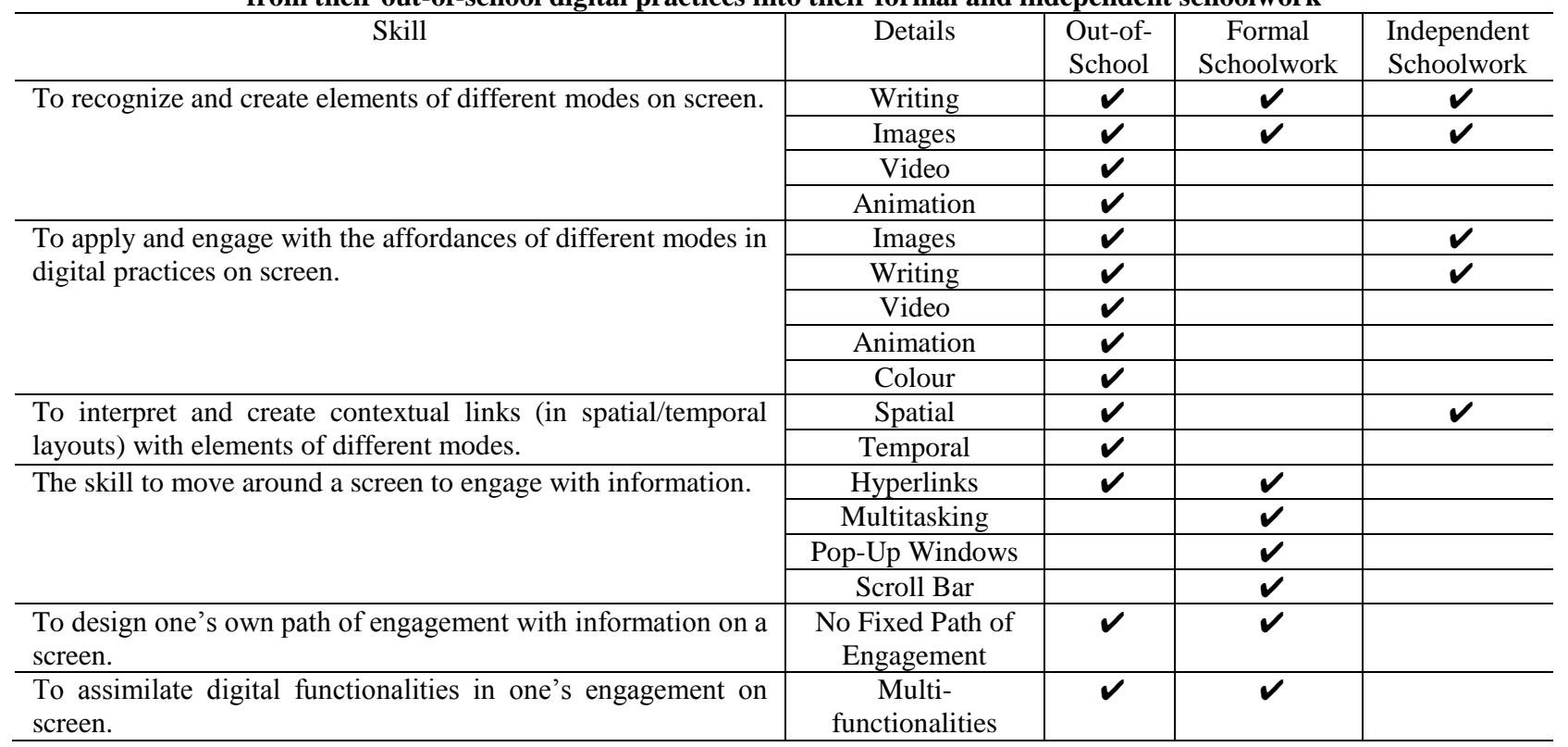

' denotes "the skill is found to be evident in the area indicated in the title of the column". 
Angel's formal learning promotes uni-mode literacy (Kress, 2003; Len Unsworth, 2008) and linear text processing(Luke, 2003). Therefore, these would seem to suggest that skill two and three were not extended.

However, the research found that children extended skills four, five and six intuitively into their formal learning on screens (as in Table 3). Furthermore, feedback from the teachers indicated the fact that they were also aware of the skills.

On the other hand, in the participants' independent schoolwork, it was noted that the children extended skills one, two and three into their independent schoolwork. Besides creating their messages meaningfully with images and writing, they were also skilled at creating meaning with contextual links with non-linear spatial layouts (skill three). However, skills four, five and six were not in evidence in their independent schoolwork. This finding may be partially attributed to the criteria set by the teachers when the schoolwork was assigned. That is, there was no teacher-led promotion of schoolwork to be completed on screens with digital texts. Rather, the teachers requested that independent schoolwork be printed to hard copy.

A pedagogical implication arises from this research. Each participant had different preferences in relation to the ways in which they engaged with digital texts. At least four different viewing and representing practices were identified, and the respective participants divided into categories as follows:

1. Multimodal practitioner - one with viewing and representing skills who prefers to engage with elements of multi-modes formats

2. Multimodal written text representing practitioner - one with viewing and representing skills that prefers to engage with writing mode format

3. Digital savvy practitioner - one who is skillful in applying digital knowledge in day-to-day activities and practices

4. Viewing practitioner - one who prefers to view but not to represent their ideas and messages on screen

Four different learning practices that emerged in the current study are consistent with the different dimensions of learning styles as reported by (Silverman \& Felder, 1988). This finding implies that education should adopt more individualized approaches to allow learners to design their own style and practice in learning. Other research also claims that different learning practices greatly affect screen-based learning performance (Huang, Lin, \& Huang, 2012). The research finding in skill five has demonstrated that children are capable of designing their own paths of engagement. Further investigation is needed to gain insight into these issues.

\section{RECOMMENDATIONS}

If digital literacies are to be effectively incorporated into primary school English Language learning, the following recommendations emerging from this study should be considered.

- $\quad$ The Primary School English Language Curriculum in Hong Kong should be revised to incorporate the six skills. The Government-mandated English Language Curriculum should not solely promote a linguistic view of literacy (with focus being on the mode of writing). This fails to connect the kinds of literacy required in the school with the "out-of-school worlds" of most people. The findings of this study have generated a deeper understanding that children have acquired at least six skills. While traditional teaching approaches to the macro skills of listening, speaking, reading and writing (The Curriculum Development Council, 2004) are clearly still vitally important, the six skills identified in this report should also be incorporated into the Language classroom in order to embrace digital text with different modes.

- $\quad$ English language learning should also promote media-mediated public pedagogy via popular culture modes such as blogs and social media. This pedagogy enhances learning on screens and promotes self-generated ideas (Richards \& Jennifer, 2010). The research findings show that children extended different skills into both formal learning and independent schoolwork (as in Table 3). Children did not extend skills two and three into their formal learning on screens. The focus on linguistic learning in a uniform model approach on screen might not optimize the benefit to learners. Children also did not extend skills four, five and six into their independent schoolwork, for which the teachers demanded hard copy printouts. Language learning 
should not be treated as a funnel where all digital literacies must be squeezed into and through the narrow passage of current print-directed meaning representations. English language with digital literacies should expand the tremendous restrictiveness of the current practices. The media-mediated public pedagogy can bridge the shortcomings of both formal learning and independent schoolwork.

- $\quad$ A self-regulated learning approach should be promoted in English Language learning. This research report has pointed out that learning materials need to be designed to incorporate different learning practices. Children do not necessarily learn in exactly the way the teaching is set. The lack of specific direction for teaching about and with digital texts has been recognized (Walsh, et al., 2007). New pedagogical strategies that support self-regulated learning, such as social media, computer games, and public pedagogy of technological spaces (Richards \& Jennifer, 2010) must be promoted, as they are drawing children away from traditional educational settings.

\section{LIMITATIONS}

The research reported on in this paper had several limitations. Although the study focused on how children extend their out-of-school digital practices into English language learning, most of the digital artifacts deriving from their out-of-school practices were not in the English language. Therefore, the research findings may not be generalizable to English Language learning on screens. Further, different subjects might have different skills of focus (Huang, et al., 2012). Future research could focus on the full range of school subjects and the essential digital skills relevant to each.

Doubt must be acknowledged as to the validity of inferences about the children's abilities to extend their skills developed from out-of-school digital practices to their independent schoolwork, since little such work was assigned. Further research could be conducted to focus on schools that do assign their students independent schoolwork on screen. Our study is focused on P5-P6 grade students (Primary Five and Primary Six); it should be highlighted that homework differs according to grades. Therefore, it may not be valid to make inferences about other grades on the basis of the current research results. Future study could focus on students of different age groups.

\section{CONCLUSION}

The current multiple case studies research identifies at least six emerging viewing and representing skills that children have acquired from their out-of-school digital practices. The writing mode was found to be the focus of the participants' learning in their English Language classrooms. However, it was observed that the children have intuitively extended some of their viewing and representing skills into their formal learning and independent schoolwork.

Although several researchers have investigated aspects of digital multimodal texts in addressing new literacies for young children (Jewitt, 2008; Kress, 2003; Martinec \& Leeuwen, 2009; L. Unsworth, 2001; Len Unsworth, Thomas, Simpson, \& Asha, 2005), the lack of specific direction in integrating digital texts into primary school English Language courses in Hong Kong is yet to be thoroughly explored. The current research provides a framework for the integration of digital texts into the primary school curriculum in Hong Kong, along with specific recommendations that emerged from the research findings and implications.

As mentioned previously, the findings of this research are not necessarily generalizable to subjects other than English Language learning on screens, since different subjects might have different skills of focus.

Future research could focus on the full range of subjects and the digital skills that might be essential in each subject, with the view to providing a set of specific guidelines for the respective subject teachers. While it is acknowledged that inferences about other subjects and grades should not necessarily be made on the basis of the current research, which is limited to primary school students of P5-P6 level, the results provide some groundwork and suggest implications for future research into language and literacy learning in primary schools. 


\section{AUTHORS INFORMATION}

Daniel Churchill is Assistant Professor at Faculty of Education, The University of Hong Kong, Pokfulum Road, Hong Kong. E-mail: dchurch@hkucc.hku.hk

Kay Yong, Khoo is an Ed.D. research student at the Faculty of Education, The University of Hong Kong, Pokfulam Road, Hong Kong. E-mail: kykhoo@yahoo.com (Corresponding author)

\section{REFERENCES}

1. Buckingham, D., \& Willett, R. (2006). Is there a DIgital Generation? In D. Buckingham (Ed.), Digital Generations. London: Lawrence Erlbaum Associates.

2. Connelly, J. (2008). Symbolic Costructions in Global Public Visuals: A Pedagogic Framework for Critical Visual Literacy. In L. Unsworth (Ed.), Multimodal Semiotics. London: Continnum International Publising Group.

3. Cope, B., \& Kalantzis, M. (Eds.). (2000). Multiliteracies: Literacy Learning and the Design of Social Futures. Melborne: Macmillan.

4. Daly, A., \& Unsworth, L. (2011). Analysis and comprehension of multimodal texts. Australian Journal of Language and Literacy, 34(1), 20.

5. Department for Children schools and families UK. (2009). The New Primary Curriculum, from http://www.dcsf.gov.uk/newprimarycurriculum/

6. Education and Manpower Bureau HK. (July 2004). Empowering learning and teching with information Technology: Government of the Hong Kong Special Administrative Region,China.

7. Gay, L. R., Mills, G. E., \& Airasian, P. (2006). Educational Research-Competencies for Analysis and Applications (8th ed.). Columbia, Ohio: Prentice Hall.

8. Gee, J. (2003). What Computer Games have to teach us about Learning and Literacy. New York: Palgrave Macmillan.

9. Huang, E. Y., Lin, S. W., \& Huang, T. K. (2012). What type of learning style leads to online participation in the mixed-mode e-learning environment? A study of software usage instruction. Computer \& Education, $58(1), 12$.

10. Jewitt, C. (2006). Technology, Literacy and Learning - A multimodal approach. Oxon: Routledge.

11. Jewitt, C. (2008). Multimodality and literacy in School Classrooms. Review of research in education, $21(1), 241$.

12. Jonassen, D. H. (1986). Hypertext Principles for Text and Courseware Design. Journal of Educational Psychologist, 21(4), 269-292.

13. Kimber, K., \& Claire, W. S. (2008). Assessing Digital Literacies: Can Assessment Ever Be the Same? In L. Unsworth (Ed.), New Literacies and the English Curriculum (pp. 328-352). London: Continuum.

14. Kress, G. (2003). Literacy in the new media age. London: Routledge.

15. Kress, G. (2010). Multimodality-A social semiotic approach to contemporary communication. Abingdon,Oxon: Routledge.

16. Kress, G., \& Jewitt, C. (2003). Multimodal Literacy. NY: Peter Lang.

17. Kress, G., \& Leeuwen, T. V. (2007). Reading Images: The Grammar of Visual Design,2nd edition. London: Routledge.

18. Leeuwen, T. V. (2005). Introducing Social Semiotics. Abingdon,Oxon: Routledge.

19. Luke, C. (2003). Pedagogy, connectivity, multimodality and interdisciplinarity. Reading Research Quarterly, 38(10), 356-385.

20. Martinec, R., \& Leeuwen, T. V. (2009). The Language of New Media Design-Theory and practice. Oxon: Routledge.

21. Merriam, S. B. (1988). Case Study Research in Education- A Qualitative Approach. San Francisco: JosseyBass Publishers.

22. Merriam, S. B. (2009). Quaitative Research-A Guide to Design and Implementation. San Francisco: Jossey-Bass.

23. Ministry of Education Ontario. (2006). The Ontario Curriculum Grace 1-8 (Language) Ontario: Ministry of Education. 
24. MOE Singapore. (2010). English Language Syllabus 2010 (Primary \& Secondary) Retrieved 10th May, 2010, from http://www.moe.gov.sg/education/syllabuses/languages-and-literature/files/english-primarysecondary-express-normal-academic.pdf

25. National Curriculum Board Australia. (2008). National English Curriculum: Initial Advice Paper Retrieved 10th November, 2009, from http://www.acara.edu.au/k6.boardofstudies.nsw.edu.au/english/english_index.html

26. Prensky, M. (2001a). Digital Natives, Digital Immigrants. On the Horizon, 9(5), 1-6.

27. Prensky, M. (2001b). Digital natives, Digital Immigrants, Part II: Do they Really Think Differently? On the Horizon, 9(6), 1-9.

28. Richards, L. F., \& Jennifer, A. S. (2010). Shaping Youth Discourse About Technology: Technology Colonization, Menifest Destiny, and the Frontier Myth in Facebook's Public Pedagogy. Educational Studies, 46, 503-523.

29. Silverman, L. K., \& Felder, R. M. (1988). Learning and Teaching Style. Engineering Education, $78(7), 8$.

30. The Curriculum Development Council. (2004). English Language Curriculum Guide (Primary 1-6) Retrieved 20th October, 2009, from http://www.edb.gov.hk/FileManager/EN/Content_2801/primary 1 6.pdf

31. Unsworth, L. (2001). Teaching Multiliteracies Across the Curriculum: Changing Contexts of Text and Image in Classroom Practice. Buckingham: Open University Press.

32. Unsworth, L. (Ed.). (2008). New Literacies and the English Curriculum. London: Continuum International Publishing Group.

33. Unsworth, L., Thomas, A., Simpson, A., \& Asha, J. (2005). Children's Literature and Computer-based Teaching. London: McGraw-Hill, Open University Press.

34. Walsh, M., Asha, J., \& Sprainger, N. (2007). Reading Digital Texts. Australian Journal of Language and Literacy, 30(1), 13.

35. Yin, R. K. (1994). Case Study Research:Design and Methods (2nd ed.). Thousand Oaks,Calif.: Sage. 